\title{
STUDIES ON DEVELOPMENT OF FUEL BRIQUETTES FOR HOUSEHOLD AND INDUSTRIAL PURPOSE
}

\author{
Ch. A. I. Raju ${ }^{1}$, K. Ramya Jyothi ${ }^{2}$, M. Satya ${ }^{3}$, U.Praveena ${ }^{4}$ \\ ${ }^{1}$ Assistant Professor, ${ }^{2,3,4}$ Student, Department Of Chemical Engineering, A.U. College of Engineering (A), Andhra \\ University, Andhra Pradesh, India
}

\begin{abstract}
The hike in the price of electricity, petrol and diesel for daily usage has directed the researches for alternate fuels. But unfortunately recession and climatic changes has increased all the expenses. This makes a tough situation for the production of alternate fuels at low cost. Among several methods fuel briquetting is widely used using municipal waste, vegetable waste, newspaper waste etc. The present investigation is carried out using Almond leaves, saw dust and cocopeat. Using proximate analysis the moisture content, ash content, volatile matter and the fixed carbon are determined. The briquette sample size is fixed as $6 \times 3 \times 3$ inches. The binding material used is plain flour in the proportion of $125 \mathrm{~g}$ per each briquette. The study incorporated the determination of calorific value, porosity, ultimate analysis, XRD, SEM analysis. The results indicated that the almond leaf briquette with higher compressive strength burns more time and is safer for storage and transportation.
\end{abstract}

Keywords: Fuel Briquettes, Calorific Value, Almond Leaf, Porosity, Deforestation. $* * *$

\section{INTRODUCTION}

Compaction of bulky combustible materials for fuel making purposes has been a technology widely used by many countries. There have been several researches carried out on production of fuel briquettes for both domestic cooking and industrial applications. One of the major driving forces behind these researches is the need to address the environmental consequences and health hazards associated with the use of solid fuels (such as fuel wood and coal) [1] and also an effective means of managing agro wastes. Among the common types of briquettes widely used in some countries are biomass briquettes, coal briquettes and charcoal briquettes, etc. However, more recently, it has been shown that blending coal and biomass (agro wastes) gives rise to a briquette with better combustion properties and pollutant emission compare to the conventional coal briquette. This type of briquette is known as biocoal briquette. Bio-coal briquette is a type of solid fuel prepared by compacting pulverized coal, biomass, binder, and sulphur fixation agent [2]. The high pressure involved in the process ensures that the coal and the biomass particles are sandwiched and adhere together, as a result do not separate during transportation, storage and combustion. During combustion, the combustion of the coal and the biomass gives a better combustion performance and reduces pollutant emission i.e. bio-coal briquette has a favourable ignition, better thermal efficiency, emits less dust and soot [3]. The mechanism behind this is that, since the biomass component of the briquette ignites at low temperature compare to the coal, this ensures that the volatile matter in the coal which would have otherwise be liberated as smoke at low combustion temperature combusts completely. The complete combustion of the volatiles reduces smoke and as well, contributes to the total heat released by the fuel. The ash of bio-coal has been shown to be effective for soil treatment and enrichment [6]. However, preserving the forest resources by substituting fuel wood with bio-coal, along with the use of the ash from this briquette for soil treatment will compensate for fossil carbon emitted by the coal component of the briquette. Therefore, bio-coal is considered to be a clean technology. Industrial methods of briquetting date back to the second part of the 19th century. In 1865 , a report was made on a machine used for making fuel briquettes from peat which is a recognizable predecessor of current machines. The use of various forms of organic briquetting seems to have been common both during World War I and during the '30s depression. The use of organic fuel-briquettes, mainly in industry, was revitalized during the period of high energy prices in the '70s and early '80s, especially in Scandinavia, the USA and Canada.

\section{MATERIALS AND METHODS}

Materials required for fuel briquetting;

(a) Agricultural wastes (b) Hand mould (c) Binding material (plain flour $\{$ maida $\}$ )

\subsection{Selection of Raw Material}

The selection of raw material is most dependent on the easily available materials in surrounding areas where the briquettes made. Another important criterion for the selection of the raw material is its ability to bond together when compressed. Thus, 
fibre-rich materials are good. Coco peat (cocopeat), also known as , coir fibre pith, coir dust, or simply coir, is made from coconut husks, which are byproducts of other industries that use coconuts. Coir waste from coir fiber industries is washed, heat-treated, screened and graded before being processed into coco peat products of various granularity and denseness, which are then used for horticultural and agricultural applications and as industrial absorbent. cocopeat is a fibrous, low-density material with a very wide range of particle sizes and hence can serve, as a best alternative for the production of fuel. Sawdust or wood dust is a by-product of cutting, grinding, drilling, sanding, or otherwise pulverizing wood with a saw or other tool; it is composed of fine particles of wood. It is also the byproduct of certain animals, birds and insects which live in wood, such as the woodpecker and carpenter ant. It can present a hazard in manufacturing industries, especially in terms of its flammability. Sawdust is the main component of particleboard. Sawdust has a variety of other practical uses, including serving as a mulch, as an alternative to clay cat litter, or as a fuel. Owning to their great density wood briquettes have a higher calorific value than the same quantity of firewood. They can be used instead of coal or wood in domestic solid-fuel stoves as well as in industrial furnaces. A significant portion of the solid waste stream is organic can potentially be briquetted. These organic wastes include leaf and yard waste as well as agricultural waste, wastewater sludge, and industrial and commercial wastes. The primary benefit of leaf and yard waste is the potential for immediate diversion of a significant portion of the state's solid waste stream from disposal facilities. The economic and environmental benefits which result from eliminating this material from disposal facilities and converting it to briquettes have provided municipalities with the incentive to establish composting operations or other useful operations. Therefore, sawdust, almond leaf and cocopeat were selected as a raw material for the carbonization that helps in mitigating both economic and environmental problems. Converting these agricultural residues into economically useful and environment friendly form of energy enables us to overcome the problems and besides that it provides the sawdust, leaf waste and cocopeat growing regions with renewable, clean and sustainable energy sources that can substitute fire wood and charcoal that was produced in traditional way.

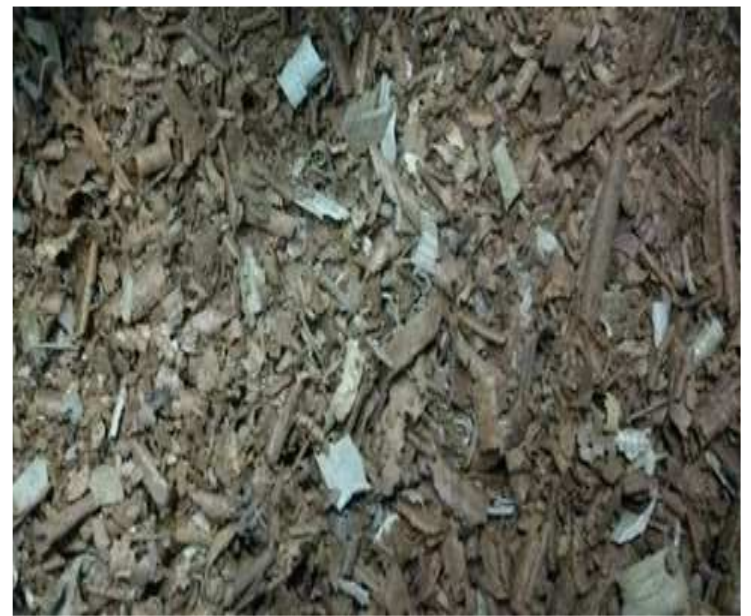

(a) Saw Dust

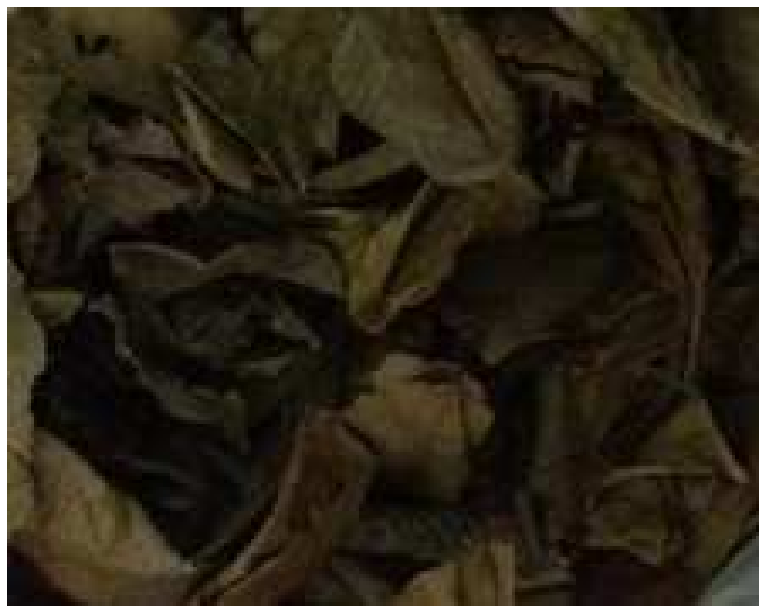

(b) Almond Leaves

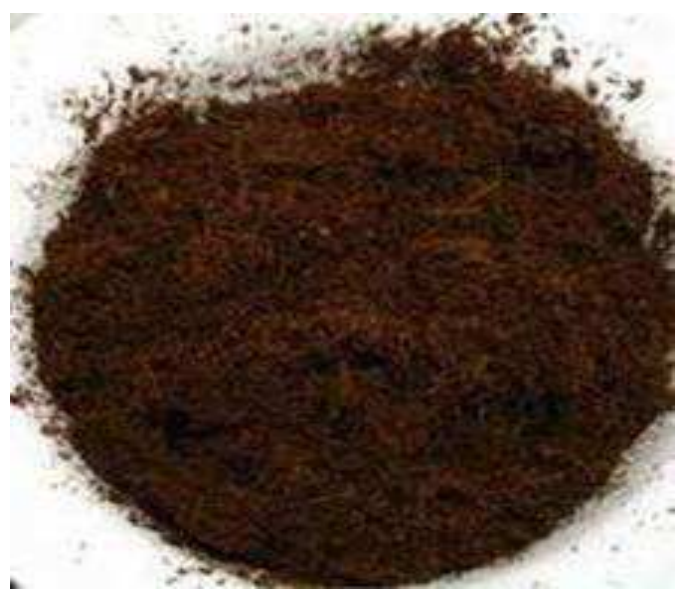

(c) Coco Peat

Fig 1 


\subsection{Hand Mould:}

The briquette mould (6" length, 3" width and 3" height) as shown in Fig 2. When the sample placed in mould and placed it in bench vice with a lid which is used for the water leaks through the holes in the mould (four holes) and a brick is formed.

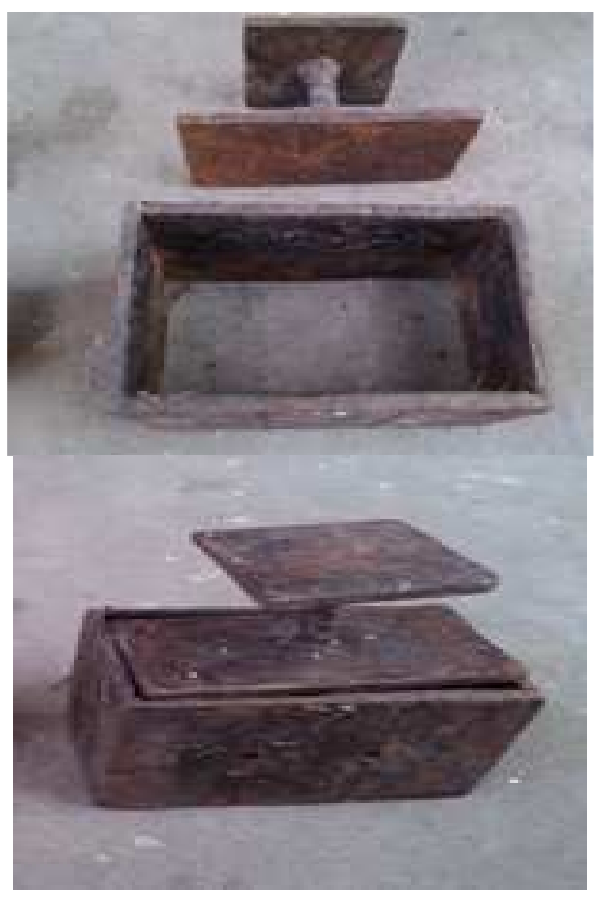

Fig- 2: Hand Mould

\subsection{Selection of Binder Material}

The binder material used for strengthening the briquettes. The carbonized char powder mixed such that every particle of char is coated with binder. It will enhance charcoal adhesion and produce identical briquettes. Two types of binders may be employed, combustible and non-combustible. Combustible binders prepared from natural or synthetic resins, animal manures or treated, dewatered sewage sludge. Noncombustible binders include clay, cement and other adhesive minerals. Although, combustible binders are preferable, noncombustible binders may be suitable if used in sufficiently low concentrations. For example, if organic waste mixed with too much clay, the briquettes will not easily ignite or burn uniformly. The binder can be commercial plain flour (maida),starch, rice powder, rice starch (rice boiled water), readily available and other cost effective materials like clay soil mixed in different proportions and shapes with the help of the briquetting machine. Flour contains a high proportion of starches. Suitable binders include starch (5 to 10\%) or molasses (15 to $25 \%$ ). Hence plain flour (maida) was selected as the binding material as shown in Fig 3 .

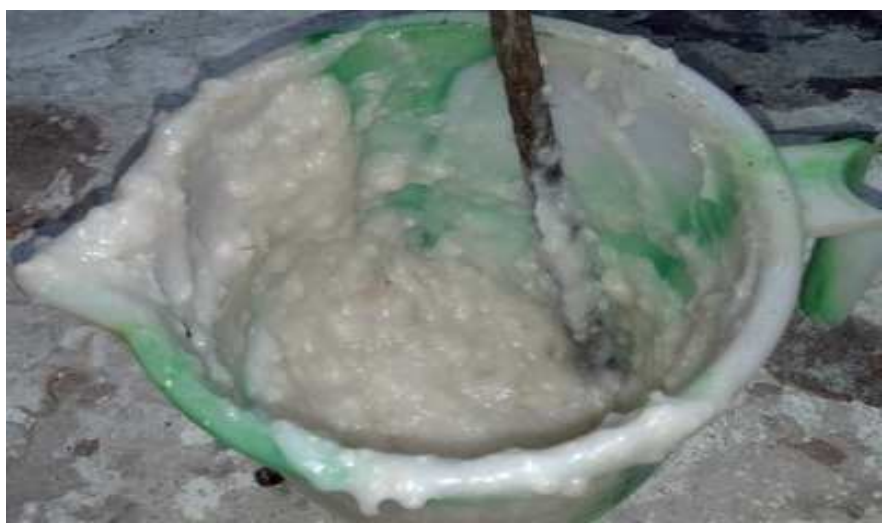

Fig-3: Preparation Of Binder (Maida)

\section{METHODOLOGY}

Biomass collection: Saw Dust, Almond Leaf waste and CocoPeat are selected as raw materials because of their availability. Saw dust and cocopeat are collected from a nearby saw mill \& coconut mills. Almond leaves were collected from Andhra University Engineering College premises.

Drying: Saw dust, Almond leaves and CocoPeat were sun dried for a period of 10 days until its moisture content was found to be around $10-15 \%$. Later their initial characteristic properties like calorific value, volatile matter and ash content were determined in three intervals. After noting the initial moisture content, proximate and ultimate analysis carried out.

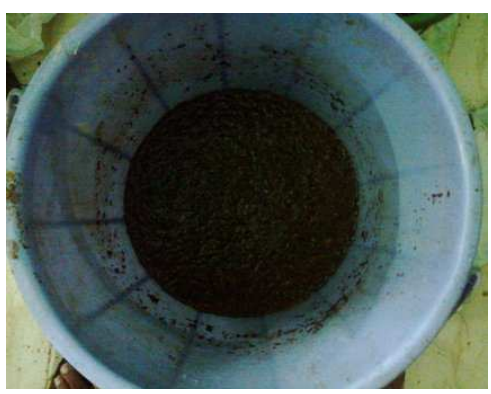

(a)

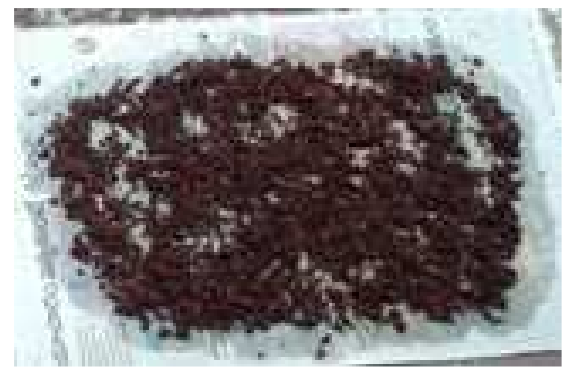

(b) 


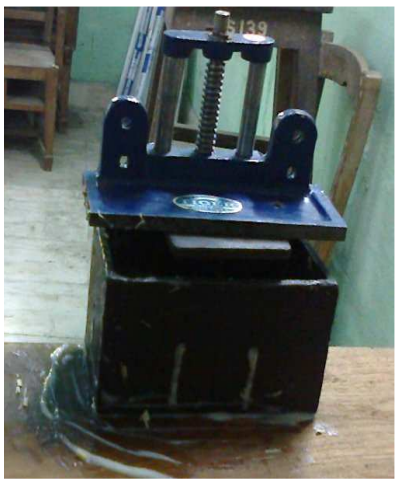

(c)

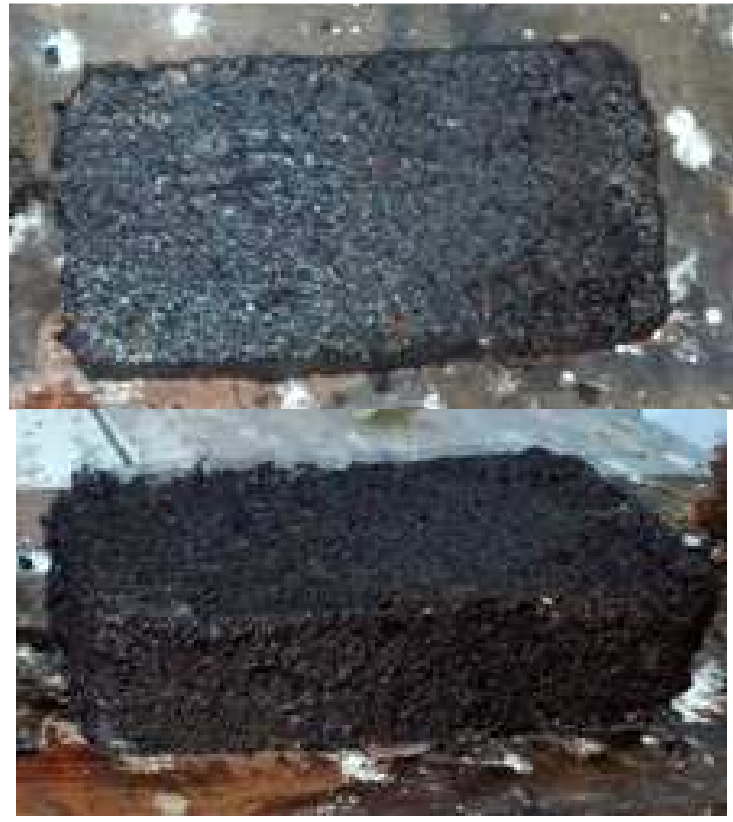

(e)

Fig-4: (a) Soaked Saw Dust, (b) Dried Saw Dust (c,d) Saw Dust Briquette In Pressing Mould (e) Formed Saw Dust Briquette

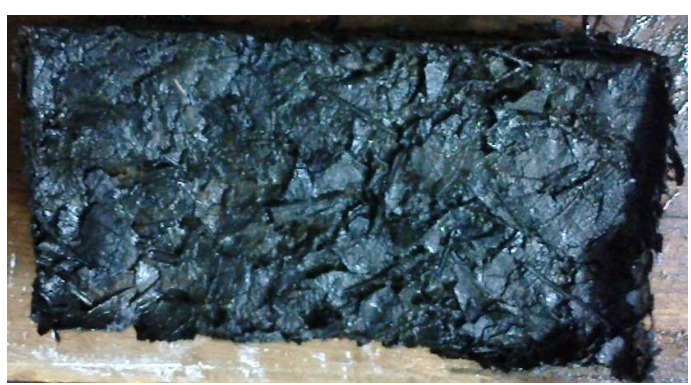

(a)

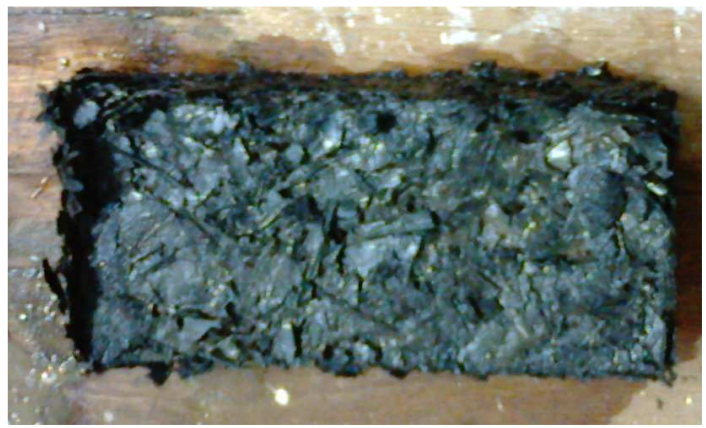

(b)

Fig-5 (a, b): Formed Badam Leaves Briquettes

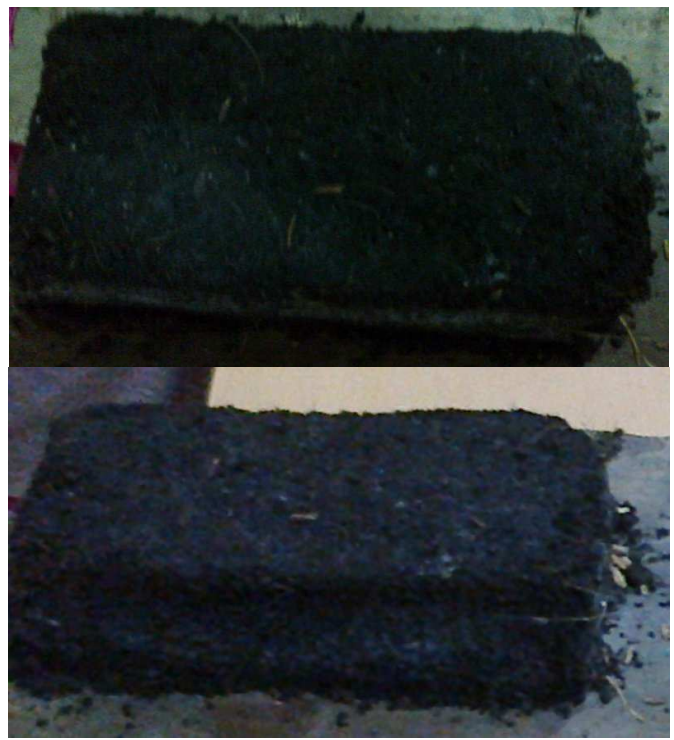

(a)

Fig 6 (a) Formed Coco Peat Briquettes

\section{RESULTS AND DISCUSSION}

\subsection{Proximate Analysis}

The proximate analysis of all the 3 samples which were carried out following the Indian Standard procedure The percentages of moisture (M), volatile matter (VM) and ash content (A) of all the samples have been shown in figure. It may be observed from table and figure that the sample no.3 has the highest moisture content (18.55\%) and sample no.1 has the lowest $(15.71 \%)$. Generally the moisture values varied from $10 \%-16 \%$. From this we conclude that sample no.3 will take more time for heating and will have lower calorific value. Also sample no. 3 will be consumed more for a certain heating purpose than other briquettes. 


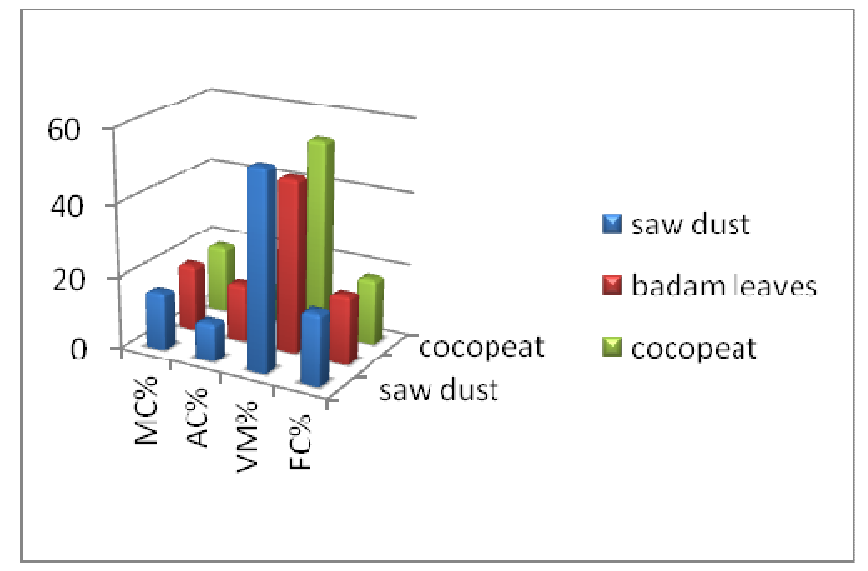

Fig-7: Percentages of MC,AC,VM,FC in different fuel briquettes.

Table-1: The proximate analysis for fuel briquettes

\begin{tabular}{|l|l|l|l|l|l|}
\hline $\begin{array}{l}\text { Sl. } \\
\text { no }\end{array}$ & $\begin{array}{l}\text { Name of the } \\
\text { sample }\end{array}$ & $\begin{array}{l}\text { moisture } \\
\text { content }(\% \\
)\end{array}$ & $\begin{array}{l}\text { ash } \\
\text { content }(\% \\
)\end{array}$ & $\begin{array}{l}\text { volatil } \\
\text { e } \\
\text { matter( } \\
\%)\end{array}$ & $\begin{array}{l}\text { fixed } \\
\text { carbon } \\
(\%)\end{array}$ \\
\hline 1 & Sawdust & 15.71 & 10.3 & 54.59 & 19.42 \\
\hline 2 & $\begin{array}{l}\text { Badamleave } \\
\text { s }\end{array}$ & 18.20 & 15.8 & 47.3 & 18.7 \\
\hline 3 & cocopeat & 18.65 & 9.8 & 53.55 & 18.1 \\
\hline
\end{tabular}

\subsubsection{Apparent water Absorption:}

Furthermore, the results of porosity index revealed that the porosity of the briquettes increases with increase in the biomass concentration. Biomass has higher inherent porosity due to its fibrous nature coupled that after pulverization, its particle sizes were relatively bigger than that of coal. These two factors offered it the ability of increasing the number of pores in the briquette. Almond leaves has low water adsorption percentage. Low porosity will hinder mass transfer during combustion due to fewer spaces for mass diffusion. The higher the porosity, the higher the rate of infiltration of oxidant and out flow of combustion/pyrolysis products during combustion and the higher will be the burning rate of the briquette.

\subsubsection{Ignition Time:}

The results of ignition time showed that the ignition time of the briquettes increases with increase in the biomass concentration. This can be explained from the fact that the biomass contains more volatile matter than the coal as shown in Table 1. Therefore, increasing its concentration in the briquette will definitely increase the ignitibility of the briquette.

\subsection{Ultimate Analysis :}

The composition of the ash-free organic component of biomass is relatively uniform. The major components are carbon, oxygen, and hydrogen. Most biomass also contains a small proportion of nitrogen and sulphur. Table 2 presents the average range of percentages. The Carbon $(\mathrm{C})$, Hydrogen $(\mathrm{H})$, Oxygen (O), Sulphur(S) and Nitrogen $(\mathrm{N})$ determination in biomass represents the so called elementary analysis. These elements are detected by an elemental analyzer. The resulting composition of biomass affects its combustion characteristics as the total overall mass of the fuel decreases during the volatile combustion phase of the combustion process, as the hydrogen to carbon ratio of the fuel increases and, to a lesser extent, as the oxygen to carbon ratio increases. Nitrogen, Sulphur and Chlorine are significant in the formation of harmful emissions and have an effect on reactions forming ash . The Sulphur and Nitrogen contents reported which are below $1 \%$ is a welcome development as there will be minimal release of sulphur and nitrogen oxides into the atmosphere, thereby limiting the polluting effect of the briquettes.

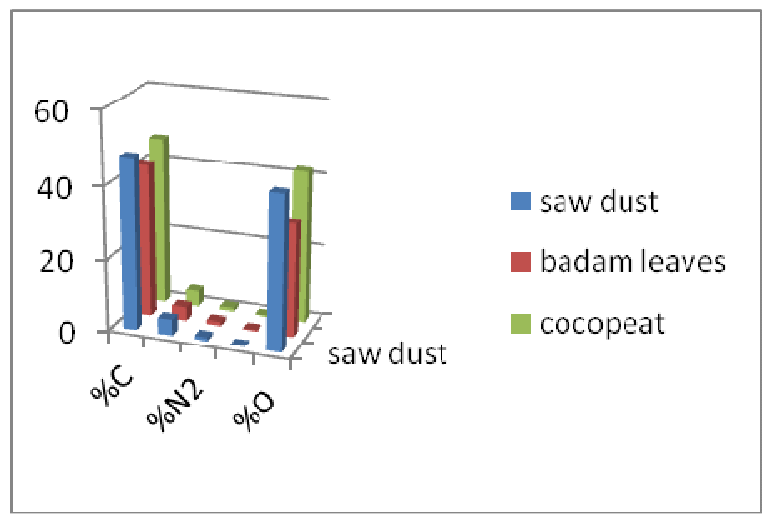

Fig-8: Percentages of C, H, N2, S, O in different fuel briquettes.

Table-2: The ultimate analysis for fuel briquettes

\begin{tabular}{|l|l|l|l|l|l|l|l|}
\hline $\begin{array}{l}\text { S1. } \\
\text { no }\end{array}$ & $\begin{array}{l}\text { Name of } \\
\text { the } \\
\text { sample }\end{array}$ & $\% \mathrm{C}$ & $\% \mathrm{H}$ & $\begin{array}{l}\% \\
\mathrm{~N} 2\end{array}$ & $\% \mathrm{~S}$ & $\% \mathrm{O}$ & Porosity \\
\hline 1 & sawdust & 47.5 & 4.5 & 1.0 & 0.04 & 42.8 & 59.79 \\
\hline 2 & $\begin{array}{l}\text { Badam } \\
\text { leaves }\end{array}$ & 42.5 & 3.8 & 1.1 & 0.35 & 31.4 & 25.23 \\
\hline 3 & Cocopeat & 46.6 & 4.4 & 1.0 & 0.26 & 42.0 & 36.30 \\
\hline
\end{tabular}

\subsection{XRD (x-ray diffraction):}

The XRD patterns of the briquettes that made from sawdust, almond leaf and cocopeat as function with percentages of ash,moisture, volatile matter, fixed carbon. The data enclosed in Table 4 shows a summary for the phases composition (\%) identified in the XRD patterns of the fuel briquettes. The 
powder XRD patterns for the starting raw material of saw dust, almond leaf and cocopeat are manifested as follows the minerals identified for saw dust are copiapite Ferrian $[\mathrm{Fe} 2+\mathrm{Fe} 3+(\mathrm{SO} 4) 6(\mathrm{OH}) 2.20 \mathrm{H} 2 \mathrm{O}]$, Ferricopiapite [Fe5(SO4)O $(\mathrm{OH}) .20 \mathrm{H} 2 \mathrm{O}]$. It can be observed that the peak increases in intensity till 2600 at resolution of $4 \mathrm{~cm}^{-}{ }^{1}$ then decreases slightly due to its partial dissolution forming ash..the minerals identified for badam leaf are Cannizzarite [Pb4 Bi6 S13] , Richetite [Pb(UO2)4 O5.4H2O] .From the fig 9, 10, 11 (a, b) it can be observed that the peak increases in intensity till 1000 at frequency of $20 \mu \mathrm{m}$ then decreases slightly due to its partial dissolution forming ash..the minerals identified for cocopeat are anorthite [Ca A12 Si2 O8 ],fizelyite [Ag5 Pb14 Sb2 S48]. It can be observed that the peak increases in intensity till 2600 at resolution of $4 \mathrm{~cm}^{-1}$ then decreases slightly due to its partial dissolution forming ash.

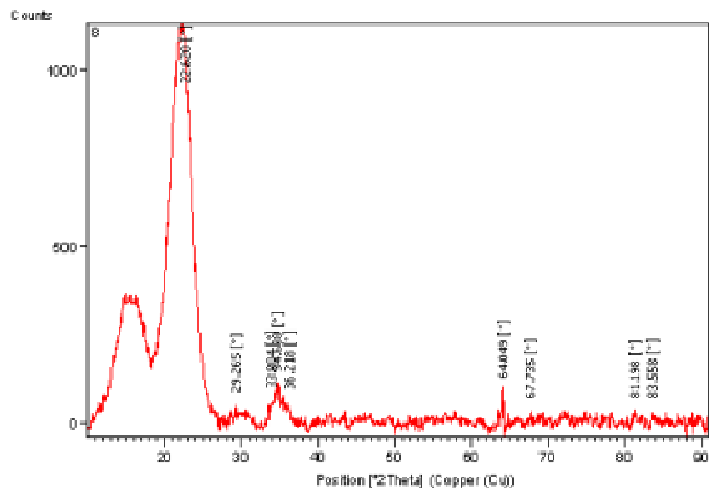

(a)

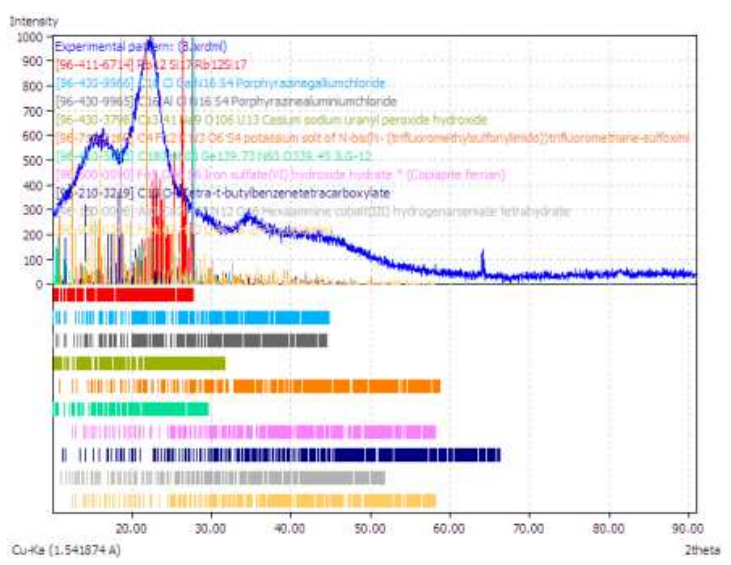

(b)

Fig-9: (a) XRD Pattern of Sawdust Sample Fuel Briquette (b): XRD Pattern of Sawdust Sample Fuel Briquette-Matching Compounds

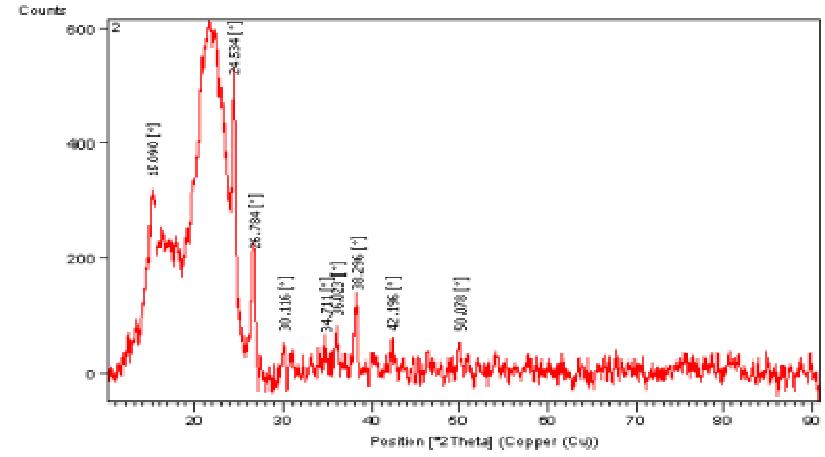

(a)

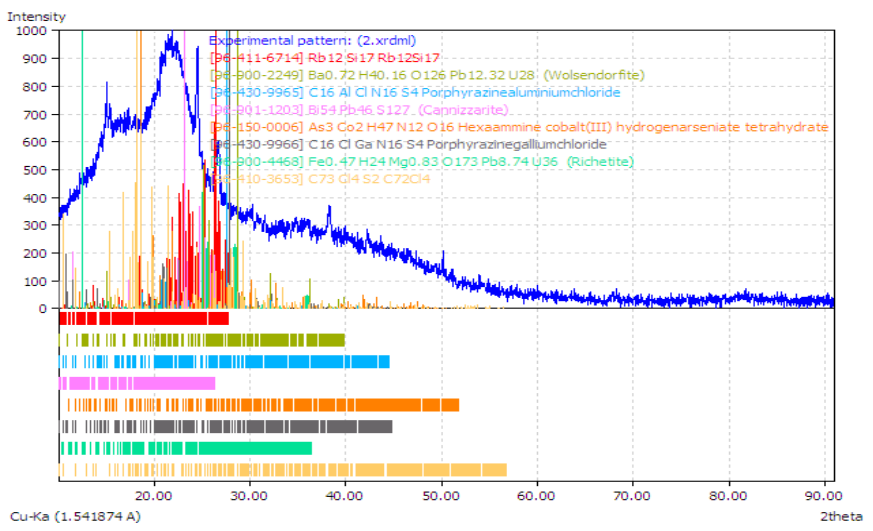

(b)

Fig -10: (a) XRD Pattern of Badam Leaves Sample Fuel Briquette (b): XRD Pattern of Badam Leaves Sample Fuel Briquette-Matching Compounds

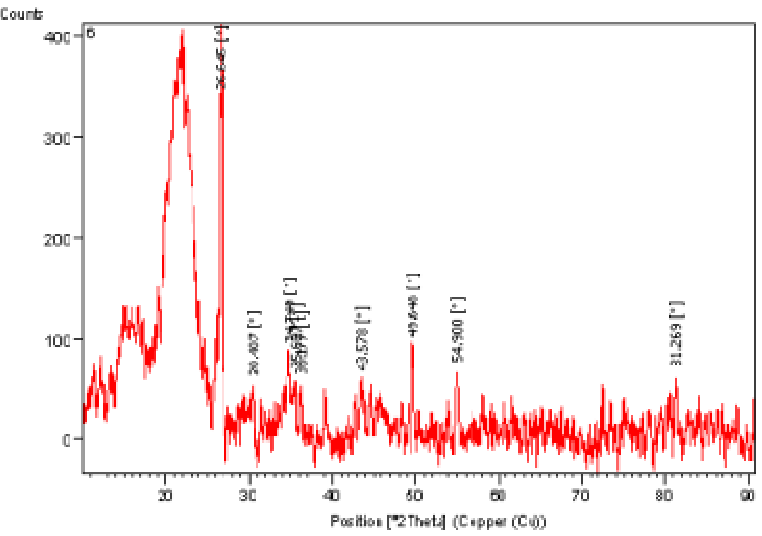

(a) 


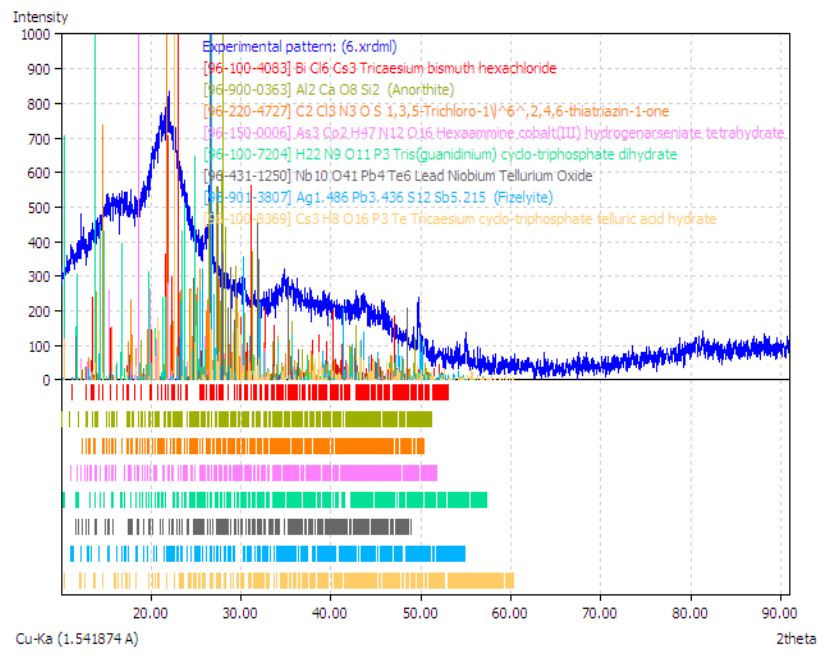

(b)

Fig-11: (a) XRD Pattern Of Coco peat Sample Fuel Briquette (b): XRD Pattern of Coco peats Sample Fuel BriquetteMatching Compounds

\subsection{SEM (Scanning Electronic Microscope):}

After the proximate \& ultimate tests, morphological and elemental analyses were applied to the samples by using SEM. According to these results it is clear that the saw dust have a typical biomass structure with respect to high volatile matter and low fixed carbon compared to coal. On the other hand, oxygen content which leads to high reactivity during thermal processes such as combustion, gasification, carbonization, and pyrolysis is very high. In addition, lignin is the dominant organic ingredient found in this biomass material. SEM image of the biomass is seen in Fig.12. This figure reveals that saw dust is very rich in fine particles and some of which have the dimensions of several microns.

\section{1 Saw Dust:}

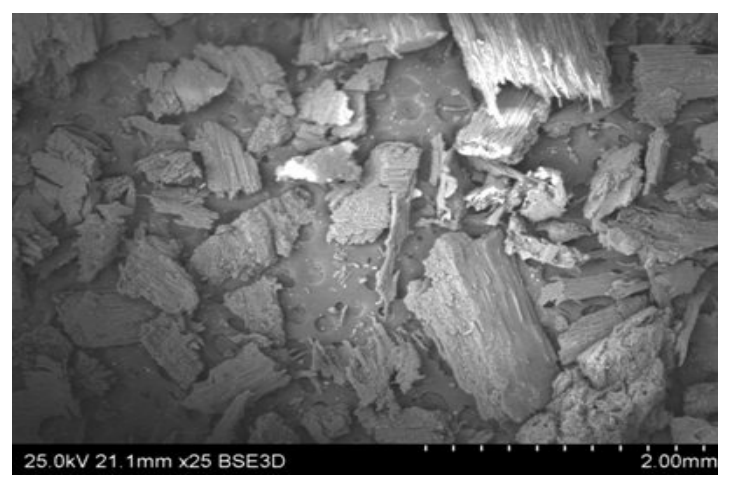

(a)

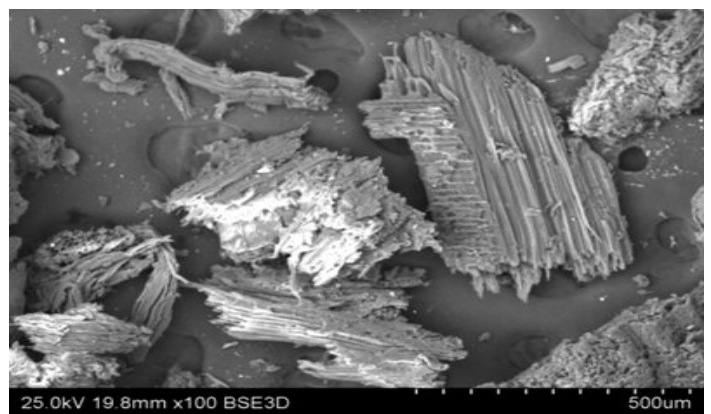

(b)

Fig-12: (a) (b) Electron Micrographs of Saw Dust Sample Fuel Briquette with 200 mm, $500 \mu \mathrm{m}$

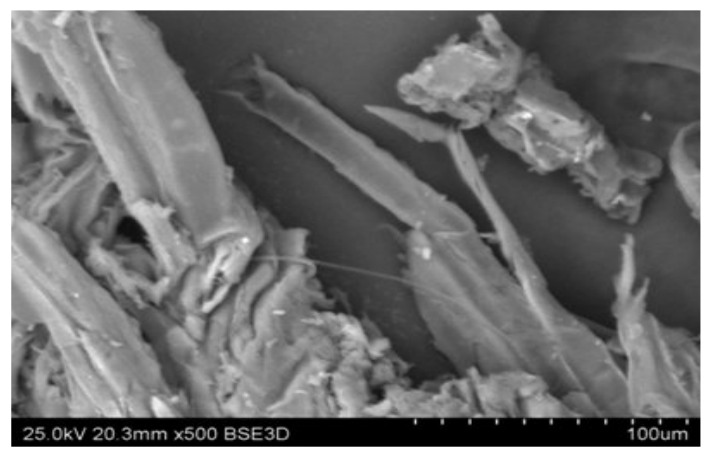

(c)

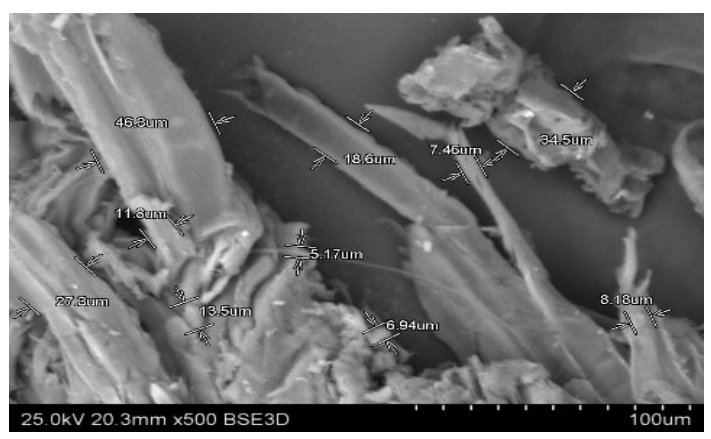

(d)

Fig-12: (c), (d) Electron Micrographs of Sawdust Fuel Briquette with $100 \mu \mathrm{m}$, various particle sizes.

\subsection{Badam Leaves:}

SEM image of the biomass is seen in Fig.13(a, b). This figure reveals that badam leaves is very rich in fine particles and some of which have the dimensions of several microns [comparison]. The below four images shows various measurements such as $200 \mathrm{~mm}, 500 \mu \mathrm{m}, 100 \mu \mathrm{m}$ respectively. Morphological structure of badam leaves samples are analysed at $2 \mathrm{~mm}$ distance $(21.2 \mathrm{~mm} \times 25), 500 \mathrm{um}(25.0 \mathrm{Kv}$ 
$21.2 \mathrm{~mm} \times 25)$, 100um $(21.5 \mathrm{~mm} \times 500), 25.0 \mathrm{kv}$ BSE 3D. Figures reveals that badam leaves waste is very rich in grain particles and some of which have the dimensions of several microns

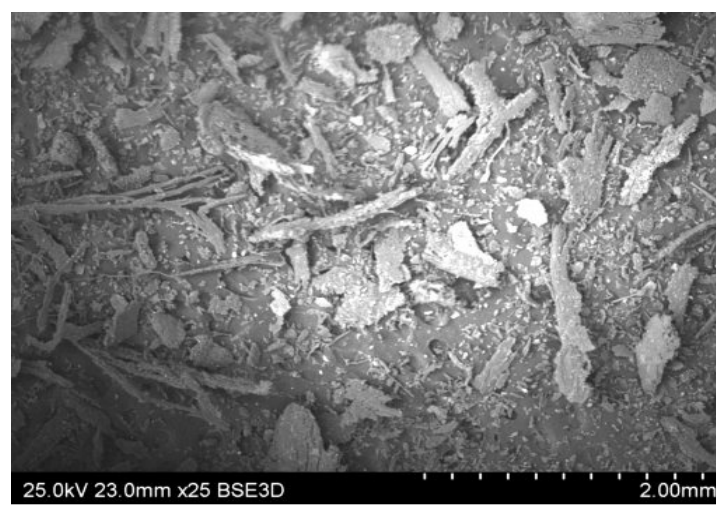

(a)

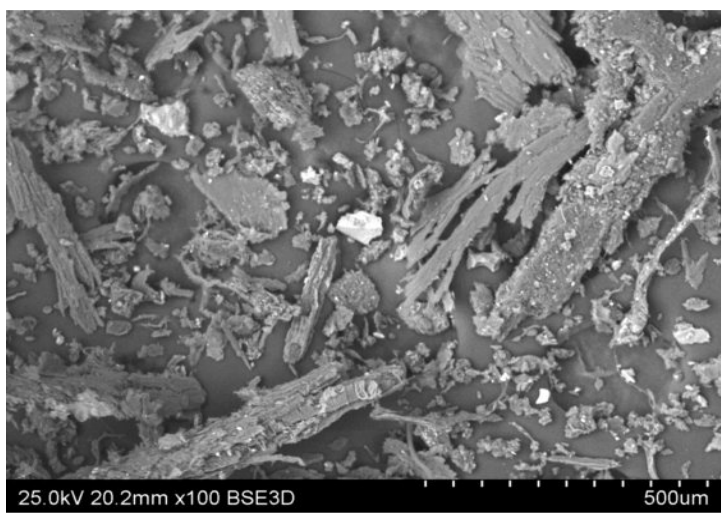

(b)

Fig-13: (a), (b) Electron Micrographs Of Sawdust Sample Fuel Briquette With $200 \mathrm{~mm}, 500 \mu \mathrm{m}$

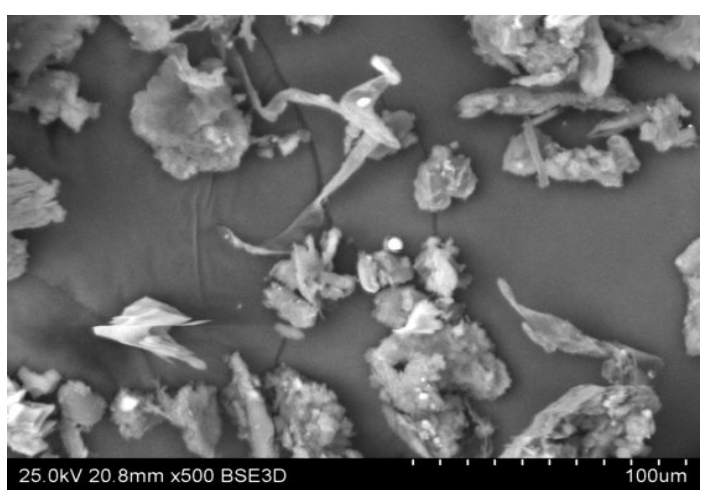

(c)

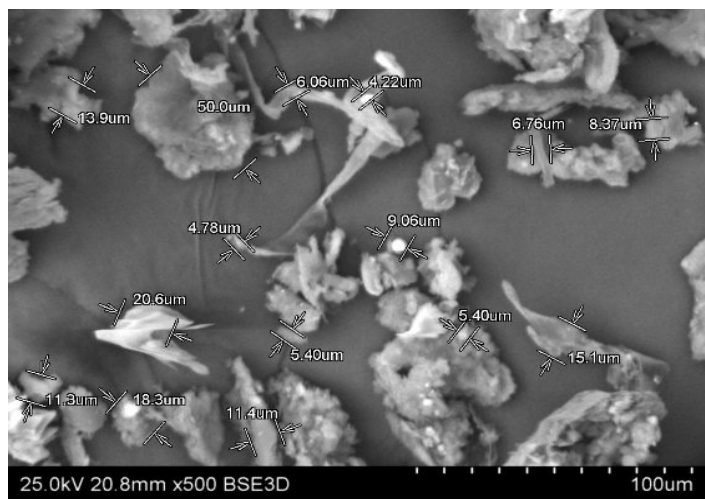

(d)

Fig-13: (c), (d) Electron Micrographs of Sawdust Sample Fuel Briquette with $100 \mu \mathrm{m}$, Particle sizes.

\subsection{Coco Peat:}

SEM image of the biomass is seen in Fig.1. This figure reveals that cocopeat is very rich in fine particles and some of which have the dimensions of several microns [comparison]. The below four images shows various measurements such as $200 \mathrm{~mm}, 500 \mu \mathrm{m}, 100 \mu \mathrm{m}$ respectively. Fig $14(\mathrm{a}, \mathrm{b})$ shows that the morphological structure of coco peat samples are analysed at $2 \mathrm{~mm}$ distance $(21.2 \mathrm{~mm} \times 25), 500 \mathrm{um}(25.0 \mathrm{Kv}$ $21.2 \mathrm{~mm} \times 25), 100 \mathrm{um}(21.5 \mathrm{~mm} \times 500), 25.0 \mathrm{kv}$ BSE 3D. Figures reveals that coco peat waste is very rich in grain particles and some of which have the dimensions of several microns. Particle size is varying from 42.1 to $96.2 \mu \mathrm{m}$. It indicates Large and small dens granulated structures shown in Fig $14(\mathrm{c}, \mathrm{d})$.

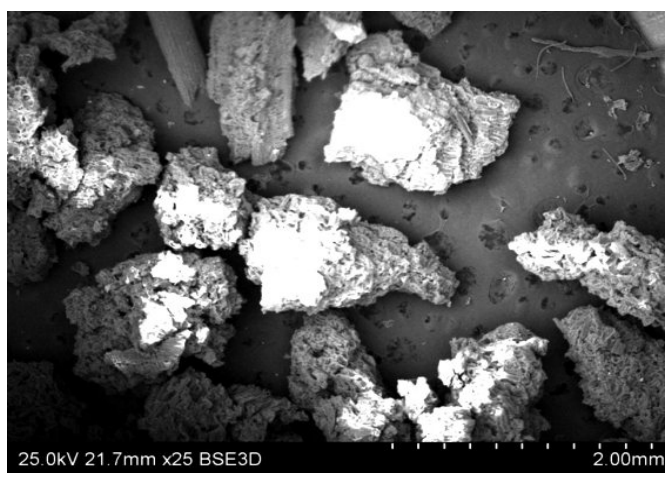

(a) 


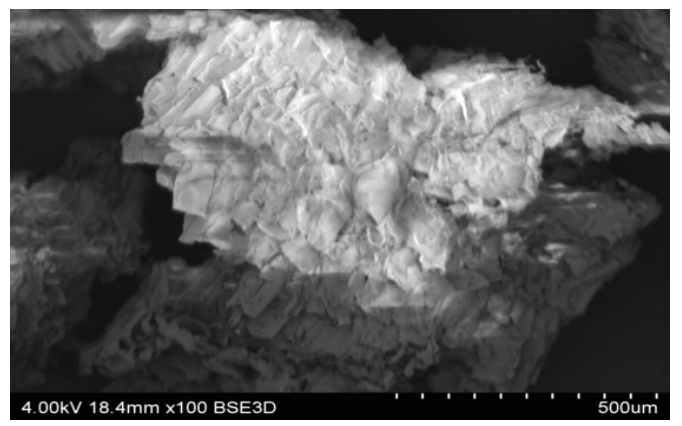

(b)

Fig-14: (a), (b) Electron Micrograph of Coco Peat Fuel Briquette with $200 \mathrm{~mm}, 500 \mu \mathrm{m}$

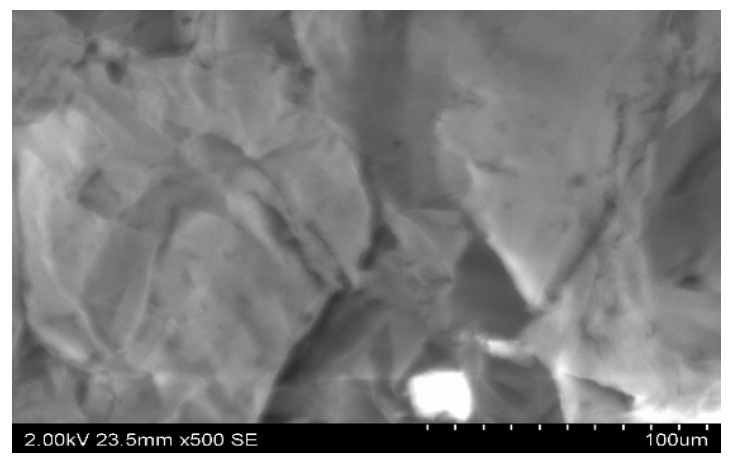

(c)

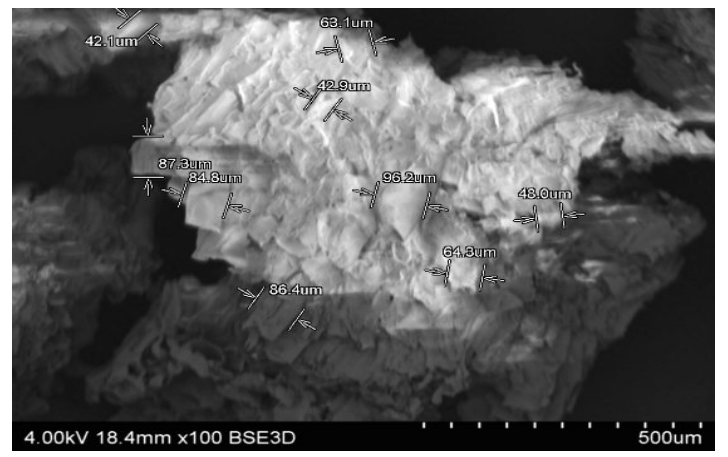

(d)

Fig-14: (c),(d) Electron Micrograph of Coco Peat Fuel Briquette with $100 \mu \mathrm{m}$, Particle Size

\section{CONCLUSIONS:}

Since the quality of any fuel briquette depends on its ability to provide sufficient heat at the necessary time, to ignite easily without any danger, generate less dust (ash) as this will constitute nuisance during cooking. The user demands and costs of fuel briquette depended on business scales. Recycling biomass can be significantly alternative fuels. The research results can be applied to develop alternative fuels. Maximum percentage of fixed carbon (19.42 per cent) was obtained from saw dust where as in almond leaf and cocopeat was 18.70 per cent and 18.10 per cent respectively. The calorific value of briquettes produced from saw dust, almond leaf and coccopeat are $4654 \mathrm{kcal}, 4237 \mathrm{kcal}, 4146 \mathrm{kcal}$ respectively The recorded data can be aimed to project images of briquette production and consumption in organized systems and macro scale for the study area. The calorific value of cocopeat was found to be which is lesser compared to the briquettes produced hence we can say that briquettes are more efficient then wood charcoal.Extension of survey areas, like business districts or SMEs, should be conducted. The manufacturing technologies involved in each step are easy to implement in rural areas, and therefore it is also provides new income generating opportunities in rural areas. The technology has a great potential for converting waste biomass into a superior fuel for household use, in an affordable, efficient and environment friendly manner. Extension of survey areas, like business districts or SMEs, should be conducted. In the application of saw dust ,almond leaf as solid fuels, forming briquettes facilitate handling, storage and transportation. The conservation of saw dust,almond leaf,cocopeat into solid fuel does not only provide fuel but also keep the environment clean, helps to check deforestation by felling of trees for fuel wood. The briquettes will serve as substitute for fuel wood since it shows superior combustion characteristics over fuel wood and the material is readily available. The briquetting process is economically, cheap and affordable to the rural and low-income urban dwellers. Besides, the binders do not contain harmful agents.

\section{REFERENCES:}

[1] Vongsaysana, "Comparison of the physical chemical properties of briquette charcoal and wood charcoal", Environment and natural resource journal", 7, Pages 12-24, 2009.

[2] Chesta Tiwari, "Producing fuel briquettes from sugarcane waste", EWB-UK National Research \& Education Journal, 220-550, Pages 39-45, 2011.

[3] Ayhan Demirbas, Ayse Sahin , Evaluation of biomass residue, "Briquetting waste paper and wheat straw mixtures", Fuel Processing Technology, 55, Pages 175-183, 1998.

[4] Grover Mishra, "Briquetting Technology and Practices", Biomass and bio energy, 8, Pages 1-48, 1996.

[5] Joel Chaney, "Combustion Characteristics of Biomass Briquette", Fuel processing technology, Progress in Energy and Combustion Science, 30(2), pages 219230, 2010.

[6] von Schirnding Y., Bruce N., Smith K., BallardTremmer G., Ezzati M., Lvovschy K., "Addressing the Impact of Household Energy and Indoor Air Pollution on the Health of the Poor: Implication for Policy 
Action and Intervention Measures", WHO, Washington DC.

[7] Patomsok W., Density Equation of Bio- Coal Briquette and Quality of Maize Cob in Thailand, American J. of Applied Science, 5(12), pages 1808-1811, 2008.

[8] Kwong P.C.W, Wang J.H, Chao C.W, Cheung C.W., Kendall G., "Effect of Co-combustion of Coal and Rice Husk on the Combustion Performance and Pollutant Emission", Atmospheric Environment, pages 74627472, 2007.

[9] Clean Coal Technology in Japan Availableat:http:www.nedo.go.jp/sekitan/cc.engpdf/2 3c3.pdf, 2009 [Accessed May, 2009].

[10] Somchai O., Kunchana B., Duangporn T., In-situ Desulfurization of Coal Briquettes by Lime, Department of Chemical Technology, Chulalondkorn University, Bangkok, Thailand, pages 1-20, 1988.

[11] Hayami H., Wake Y., Kojima T., Yoshioka K., Biocoal Briquettes and Planting Trees as an Experimental CDM in China. Keio Economic Observatory Discussion Paper, G.No 136, Tokyo, Japan, pages 1-20, 2001.

[12] ERIKSON, S. and PRIOR, M "The Briquetting of Agricultural Waste for Fuel", FAO Environment and Energy paper 11, FAO of the UN, Rome, 1990.

[13] FRANCIS, W. and PETERS M.C. "Fuel and Fuel Technology", Pergamon Press Publishing, United Kingdom pages 101-106. 1965.

[14] Forestry Residues", Proceedings of the sixthCanadian Bio-energy R \& D Seminar held out Richmond, British Columbia, pages 16-18, 1965.

[15] GROVER, P.D. and MISHRA, S.K. "Biomass Briquetting; Technology and Practices", FAO of the UN, Bangkok, 1996.

[16] MUKHYLONOV, J.P. "Fundamentals of Chemical Technology", Mir Publishers, Moscow, pages 200-201, 1986

[17] SEN, K.C. "Development of Water Densified Solid Fuel Pellet from SYBIL", P. P. 1958.

[18] "McGraw Hill Encyclopedia of Science and Technology", McGraw Hill, Inc. Limited 6thedition vol. 15 , page $466-467$. 